\author{
Alicja Korzeniecka-Bondar \\ Uniwersytet w Białymstoku \\ e-mail: alibon@uwb.edu.pl
}

\title{
Wychowanie w kulturze - kultura wychowania
}

Niemalże sześćdziesiąt lat temu Wincenty Okoń rozpoczynał swój tekst Problemy OSOBOWOŚCI NAUCZYCIELA tymi słowami:

[w]ychowanie stanowi jeden z fundamentalnych czynników rozwojowych każdego społeczeństwa. Spełnia ono swe zadania należycie wówczas, gdy przygotowuje młode pokolenia do uczestnictwa w życiu i kulturze społeczeństwa, narodu i ludzkości, do mądrej przebudowy tegoż życia i tej kultury, gdy przyczynia się do wytwarzania więzi pożądanych ze społecznego punktu widzenia, integrujących społeczeństwo, naród, ludzkość. Niedoskonałe lub złe wychowanie - pozostając z tymi celami w sprzeczności i przyczyniając się do rozkładu społecznego - staje się samo w sobie sprzecznością, bowiem w istocie wychowania leży czynić ludzi lepszymi, społeczeństwa - lepiej zorganizowanymi (Okoń, 1959, s. 5).

Czy słowa te tracą dziś na ważności, aktualności? Wręcz przeciwnie, oddajemy do rąk Czytelników numer, zawierający artykuły naukowe, w których wybrzmiewa istota wypowiedzi nestora polskiej pedagogiki. Wychowanie jest procesem, który doczekał się bogatej literatury i licznych studiów, które nie sposób tu przywołać, stąd też podaje jedynie wybrane przykłady ujęć całościowych (Gurycka, 1979, 1990, 1997; Kunowski, 1996, 2000, 2003; Łobocki 2001, 2003; Nowak, Ożóg, Rynio, 2003; Śliwerski, 2005; Dudzikowa, Czerepaniak-Walczak, 2007, 2008, 2010). Jednak zmieniający się kontekst, przemiany kultury implikują potrzebę ponawiania refleksji nad wychowaniem zarówno jako procesem, jak i pojęciem, dostrzegania szeregu znaczeń i dylematów (Śliwerski, 2007). Autorzy piszący do tego numeru „Parezji” nie udzielają odpowiedzi na pytanie: jak wychowywać (Pellegrino, 1994; Tarnowski, 1993, 2003) w obecnym świecie, ale uwrażliwiają na bogactwo perspektyw w postrzeganiu zjawisk, na dialog i delikatność myślenia, talent pedagogiczny, pasję i znaczenie szeroko rozumianej sztuki. Podejmującym analizy nad pro- 
cesem wychowania proponują zapomniane i/lub na nowo odczytane tropy mogące stanowić inspirację do namysłu i działania pedagogicznego.

Jarosław Gara tekstem pt. KULTURA WYCHOWANIA JAKO FENOMEN DROGI OKRĘŻNEJ wprowadza w rozumienie, kluczowych dla podejmowanych rozważań, kategorii. Pojęcie „kultury wychowania” traktuje w kategoriach umownego konstruktu teoretycznego, dzięki któremu ujęte są, z punktu widzenia myślenia i działania pedagogicznego, swoiste sensy i znaczenia. Wykorzystana w tekście przestrzenna metafora drogi okrężnej stanowi heurystyczny trop w próbie ujęcia owych sensów i znaczeń. Autor odróżnia zakresy znaczeniowe metafor drogi bezpośredniej, drogi na skróty, drogi okrężnej oraz drogi donikąd, a następnie przywołuje wybrane kulturowo-filozoficzne zastosowania toposu drogi okrężnej, by dookreślić pojęcia homo culturalis oraz mondo civile z perspektyw pojęcia kultury jako drogi okrężnej. To stanowi podstawę do ujęcia samej kultury wychowania poprzez: sformułowanie założeń określających rozumienie tego pojęcia z perspektywy metafory drogi okrężnej; określenie egzystencjalnego etosu, wyrażonego w nastawieniach i racjach myślenia i działania pedagogicznego; wyodrębnienie czterech postaci racjonalizacji i utrwalania egzystencjalnych habitusów w ramach oddziaływań pedagogicznych.

Łukasz Michalski, dokonuje analizy przemian kategorii talentu pedagogicznego. W studium zatytułowanym TALENT PEDAGogiCZnY 2.0 (MEANDRY AKTUALIZACJI) wskazuje na nośność tej kategorii wykorzystując trzy konteksty organizujące wywód: filozoficzne i teoretycznoliterackie rozważania dotyczące ironii (Michał Paweł Markowski, Paul de Man); koncepcję kulturowego szaleństwa (Michel Foucault) oraz rozważania Thomasa Stearnsa Eliota na temat napięć między talentem poetyckim i tradycją, co miało na celu aktualizację tytułowej kategorii dla teraźniejszości.

Markus Lipowicz w tekście pt. PedAgogiczne implikaCJE FILOzofiI KUltury I ŻYCiA LUdWigA WitTgensteinA - ZARYs Problematyki stawia hipotezę, iż myśl Wittgensteina może stanowić istotną alternatywę dla postmodernizmu zainspirowanego filozofią Nietzschego, skoncentrowanego wokół idei transgresji i indywidualizmu egocentrycznego. Po krótkim omówieniu pojęcia ponowoczesności w pierwszej części tekstu, rozwija pojęcie wychowania, które wyłania się z myśli wiedeńskiego filozofa. Autor TRAKTATU LOGICZNO-FILOZOFICZNEGo proponował postawę pokory wobec tego, czego nie sposób wyrazić w języku naukowym i metafizycznym, co zaś manifestuje się w życiu społecznym w rozmaitych rytuałach i ceremoniach i daje jednostce zdolność pojmowania swojej egzystencji jako sensownej. Ponowoczesny impet filozofii Wittgensteina polega, zdaniem Lipowicza, na zdystansowaniu się wobec typowego dla nowoczesności nieustannego postępu oraz 
wynikającego z niego poczucia wyższości wobec przednowoczesnych, archaicznych form życia społecznego.

O rekonstruowanie przeszłości w procesie edukacji muzealnej upomina się Renata Pater w materiale przeglądowym Edukacja MUzealna - WYCHOwaNiE Do AKTYWNego uCZestnictwa w Kulturze. Autorka ukazuje muzeum jako ważny obszar badań edukacyjnych, który w Polsce stosunkowo mało jest eksplorowany, w szczególności przez środowisko pedagogów. Na wybranych przykładach działań prowadzonych przez muzea wskazuje, że stanowią one aktualną i ważną przestrzeń dla wychowania do aktywnego uczestnictwa w kulturze.

Teatr szkolny, w przekonaniu Edyty Nieduziak, stanowi element kultury szkoły. W artykule o tytule Co SIĘ STA£o Z TEATREM SZKolnym? W POSZUKIWANIU ZAGUBIONEGO OBSZARU KULTURY SZKOŁY prezentuje zmienne cele teatru szkolnego uzależnione od kontekstów społeczno-kulturowych. Szczególną uwagę poświęca autorka czasom dwudziestolecia międzywojennego, które uważane są za jedne z najbardziej rewolucyjnych w praktyce i poglądach na teatr szkolny. Autorka stwierdza, że zanikająca aktywność uczniów w sferze pracy w szkolnym teatrze uwarunkowana jest m.in. współczesnym nastawieniem na szybki i spektakularny sukces oraz na kształtowanie postaw odbiorczych.

Kulturoznawca i medioznawca Wojciech Siwak analizuje problematykę cyborgizacji, cyborgów, którą rozpoznać powinni współcześni pedagodzy. W artykule Problemy edukacji w erZe cyborgów. SPOJRZENIE Z dYSTANSU szeroko je analizuje. Rozwijając pojęcie ekstensji i immersji, zwraca uwagę na komponenty wirtualizacji edukacji, zastanawiając się, czy może ona podążać w kierunku pedagogiki cyborgów czy cyberpedagogiki, jakie mogą być tego potencjalne skutki oraz możliwe bariery. Omawia też trendy edukacyjne, wskazując na wymuszane przez nowe tendencje edukacyjne i nowe technologie zmiany roli nauczyciela, zmiany przestrzeni edukacyjnej, przy jednoczesnej trosce pedagogów o wychowanie zorientowane na osobę. Podsumowując formułuje postulaty dotyczące aksjologii maszyn $v s$ aksjologii człowieka, mające istotne znaczenie nie tylko w kontekście edukacji i wychowania, ale generalnych pytań o conditio humana w erze cyborga. POSTSCRIPTUM nadesłane przez Wojciecha Siwaka jest niejako dopełnieniem jego tekstu, choć dotyczy zupełnie innego wątku. Głos ten traktujemy jako troskę o jakość naukowej dyskusji (prowadzonej nie tylko w „Parezji”). Pragnęlibyśmy, by ta krótka wypowiedź zainicjowała szerszą debatę dotyczącą tego, co dzieje się na uniwersytecie, a co sami jako autorzy, recenzenci współtworzymy, lub przeciwko czemu - jak uczynił to Wojciech Siwak - się sprzeciwiamy. 
Tekst Jerzego Nikitorowicza, Ku NOWEMU PARADYGMATOWI TOLERANCJI W KULTURZE ZRÓŻNICOWANIA ŻYCIA AKADEMICKIEGO także jest wyrazem sprzeciwu wobec, zaproponowanej przez profesora Piotra Nowaka, koncepcji ograniczonej dyskryminacji stosowanej na uniwersytecie (opublikowanej w styczniu 2017 w „Rzeczpospolitej”). Profesor J. Nikitorowicz wskazuje na potrzebą poszukiwania nowego paradygmatu tolerancji w kulturze życia akademickiego, na potrzebą decentracji interpersonalnej, którą uważa za pierwszy krok kreujący ów paradygmat. Decentrację interpersonalną ujmuje jako rozpatrywanie stosunków z innymi ludźmi, sytuacji i zjawisk, jednocześnie z różnych perspektyw, bez subiektywnej deformacji obrazu analizowanych zjawisk. W tekście Autor, jako wieloletni rektor, dziekan, ale przede wszystkim pedagog międzykulturowy formułuje szereg pytań, które stanowić mogą wartościowy przyczynek do autorefleksji nauczycieli akademickich (zwłaszcza tych będących na początku drogi naukowej), do określenia własnego miejsca i roli w tworzeniu paradygmatu tolerancji w kulturze życia akademickiego. Nawiązując do tytułu tekstu kolejnego Autora, można powiedzieć: Nie będzie uniwersytetu, gdy nie będzie wspólnej troski o jego kształt.

Profesor Uniwersytetu Śląskiego, literaturoznawcza, poeta, eseista, tłumacz Tadeusz Sławek, po wygłoszeniu inauguracyjnego wykładu na XXX Letniej Szkole Młodych Pedagogów w Katowicach (Tomas, 2016; Maliszewska, Michalski, 2016), przyjął zaproszenie przygotowania tekstu do „Parezji”. Tytuł wystąpienia NIE BęDZIE ZYSKU, GDZIE NIE MA RADOŚCi tylko z pozoru brzmi jak reklama przyjemnych i lukratywnych inicjatyw. Autor dopiskiem EDUKACJA, JEDNOSTKA, wSPÓLNOTA dookreśla pole problemowe własnej wypowiedzi. Profesor T. Sławek stawia w tekście tezę: „potrzebna nam jest szkoła, która od początku uczy niedostosowywania się do uznanych sposobów organizacji świata, co oznacza zgodę na jego obecny kształt, ale pobudza postawy rozumnej niezgody i konstruktywnego sprzeciwu" (czy nie koresponduje to ze słowami W. Okonia, że wychowanie ma przygotowywać: „do mądrej przebudowy tegoż życia i tej kultury"?). Autor upomina się o potrzebę kształcenia delikatności myślenia, z której w dalszej kolejności wynikają: troska o to, co „małe”; wypowiadanie posłuszeństwa niecierpliwości świata domagającego się od nas, aby być „tym” lub „tamtym”; sprzeciw wobec przekonania, że to zawodowi przysługuje ostateczne prawo określania tego, kim jest człowiek. Literaturoznawca ukazuje, jak można szukać inspiracji pedagogicznych w szeroko pojętej kulturze, dokonując tego w mistrzowski sposób z wykorzystaniem dzieł Williama Szekspira. W czasie, gdy finalizowaliśmy pracę nad numerem prof. dr hab. T. Sławek uzyskał Nagrodę im. Adama Mickiewicza za wybitne zasługi dla polskiej literatury i kultury (Szostak, 2017). Serdecz- 
nie gratulujemy i tym bardziej cieszymy się, że jego tekst współtworzy ten numer.

O kontakcie z dziełami muzycznymi i formacyjnej roli uczestnictwa w chórze uniwersyteckim Krzysztof Czykier rozmawia z profesorem Edwardem Kulikowskim pełniącym od 40 lat funkcje dyrygenta Chóru Uniwersytetu w Białymstoku, laureatem wielu nagród. Osoby znające profesora Kulikowskiego wiedzą, że jest to człowiek niezwykły - wrażliwy, serdeczny, ale także wymagający i nieprzymykający oczu na bylejakość, pozór i krzywdę. Jest to także człowiek wielkiej pasji, posiadający (nie od dziś!) marzenia, co zapowiada tytuł rozmowy: Mieliśmy MARZENIA, żEBY UCZESTNICZYĆ W PRAWDZIWYM ŻYCIU ARTYSTYCZNYM, i potrafiący pociągnąć za sobą wiele osób. Podwójny Jubileusz - Chóru Uniwersytetu w Białymstoku i Dyrygenta - stanowił przyczynek do refleksji nad znaczeniem tradycji, ciągłości w kulturze teraźniejszości oraz kontekstów formacyjnych, wychowawczych realizowanych w muzyce i poprzez muzykę.

W dziale Studium Recenzyjne publikujemy analizę Aliny Wróbel, wydanej w 2016 roku, przez Wydawnictwo Wolters Kluwer, monografii zbiorowej pt. Twierdza. Szkoła w metaforze militarnej. Co w zamian? redagowanej przez Marię Dudzikową i Sylwię Jaskulską. Praca otwiera nową serię publikacji pedagogicznych, którą redaguje Maria Dudzikowa i Ewa Bochno, noszącą tytuł „Kultura Szkoły”. Recenzentka poleca przeczytanie tego tomu wskazując na nośność i wzorcowe wykorzystanie metafory militarnej jako narzędzia analitycznego, a także na interdyscyplinarną perspektywę teoretyczną. W dziale tym drukujemy także recenzję "Rocznika Pedagogicznego" t. 39 (red.) Marii Dudzikowej przygotowaną przez Renatę Nowakowską-Siutę. Przytoczę tylko jeden, ale nie jedyny, powód dla którego poprosiliśmy o jej przygotowanie - ponad jedną trzecią Autorów piszących w tym tomie stanowią członkowie Forum Młodych Pedagogów przy Komitecie Nauk Pedagogicznych PAN (czytaj uczestników Letnich Szkół Młodych Pedagogów) nie wliczając naszych Mistrzów. Chciałoby się zawołać „dobra nasza... I tego trzymać się trzeba".

Numer wieńczy autorefleksja nad własnym działaniem podejmowana przez Ewelinę Bochno i Radosława Nawojskiego, O WZAJEMNYM „NAKRĘCANIU SIĘ" WE WSPÓLNYM DZIAŁANIU. AKCJa CHARYTATYWNA STUDENTEK I STUDENTów socjologiI UJ „Aleppo płonie, świat milczy”. Autorzy podejmują próbę refleksji nad mechanizmami sprawiającymi, że wspólna aktywność łączy i staje się - jak mówią - motorem „nakręcania” kolejnych działań. Ilustrują to przykładami własnego działania podczas akcji charytatywnej studentów socjologii Uniwersytetu Jagiellońskiego pt. „Aleppo płonie, świat 
milczy”. Opisywani młodzi ludzie zdają się czynić to, co stanowi, określoną przez W. Okonia, istotę wychowania: „czynić ludzi lepszymi, społeczeństwa - lepiej zorganizowanymi” (Okoń, 1959, s. 5).

Tomasz Szlendak analizując właściwości współczesnych odbiorców wielozmysłowej kultury iwentu stwierdza, że pobudzanie jednego tylko zmysłu traktują jako „nudę i stratę czasu” (Szlendak, 2010, s. 94). Zachęcamy zatem do czytania niniejszego numeru i równoczesnego pisania tekstów do kolejnego poświęconego `Projektowi UNIVERSITAS« w którym przyjrzymy się temu, jakim jest i staje się obecnie uniwersytet.

\section{BIBLIOGRAFIA}

Dudzikowa, M., Czerepaniak-Walczak, M. (red.). (2007). Wychowanie: pojęcia, procesy, konteksty: interdyscyplinarne ujęcie. T. 1-3. Gdańsk, Sopot: Gdańskie Wydawnictwo Psychologiczne.

Dudzikowa, M., Czerepaniak-Walczak, M. (red.). (2008). Wychowanie: pojęcia, procesy, konteksty: interdyscyplinarne ujęcie. T. 4. Gdańsk, Sopot: Gdańskie Wydawnictwo Psychologiczne.

Dudzikowa, M., Czerepaniak-Walczak, M. (red.). (2010). Wychowanie: pojęcia, procesy, konteksty: interdyscyplinarne ujęcie. T. 5. Gdańsk, Sopot: Gdańskie Wydawnictwo Psychologiczne.

Gurycka, A. (1979). Struktura i dynamika procesu wychowawczego. Warszawa: Państwowe Wydawnictwo Naukowe.

Gurycka, A. (1990). Błąd w wychowaniu. Warszawa: Państwowe Wydawnictwo Naukowe.

Gurycka, A. (1997). O sztuce wychowania dla wychowawców i nauczycieli. Warszawa: CODN.

Kunowski, S. (1997). Podstawy współczesnej pedagogiki. Warszawa: Wydawnictwo Salezjańskie.

Kunowski, S. (2000). Problematyka współczesnych systemów wychowania. Kraków: Oficyna Wydawnicza „Impuls”.

Kunowski, S. (2003). Wartości w procesie wychowania. Kraków: Oficyna Wydawnicza „Impuls".

Łobocki, M. (2001). Wychowanie moralne w zarysie. Kraków: Oficyna Wydawnicza „Impuls”.

Łobocki, M. (2003). Teoria wychowania w zarysie. Kraków: Oficyna Wydawnicza „Impuls”.

Maliszewska, K., Michalski, Ł. (2016). Jubileusz, czyli pragnienie sacrum. (O)powieść o XXX Letniej Szkole Młodych Pedagogów. Rocznik Pedagogiczny, t. 39, s. 263-275.

Nowak, M., Ożóg, T., Rynio, A. (red.). (2003). W trosce o integralne wychowanie. Lublin: Wydawnictwo Katolickiego Uniwersytetu Lubelskiego.

Okoń, W. (1959). Problemy osobowości nauczyciela. W: W. Okoń wstęp. Osobowość nauczyciela. Rozprawy (s. 5-24). Warszawa: Państwowe Zakłady Wydawnictw Szkolnych.

Pellegrino, G. (1994). Jak wychowywać? Warszawa: Wydawnictwo Salezjańskie.

Szlendak, T. (2010). Wielozmysłowa kultura iwentu. Kultura Współczesna, 4(66), s. 92-109.

Szostak, V. (2017). Poznańska Nagroda Literacka 2017. Tadeusz Sławek laureatem, nominacje dla trojga młodych autorów. Gazeta Wyborcza, 24 kwietnia 2017 Pozyskano z: http://poznan.wyborcza.pl/poznan/7,36001,21682758,poznanska-nagroda-literacka-2017-tadeuszslawek-laureatem.html [data dostępu: 25.04.2017].

Śliwerski, B. (2005). Współczesne teorie i nurty wychowania. Wyd. V. Kraków: Oficyna Wydawnicza „Impuls”. 
Śliwerski, B. (2007). Wychowanie. Pojęcie - znaczenia - dylematy. (s. 25-76). W: M. Dudzikowa, M. Czerepaniak-Walczak (red.). Wychowanie: pojęcia, procesy, konteksty: interdyscyplinarne ujęcie. (T. 1-3). Gdańsk, Sopot: Gdańskie Wydawnictwo Psychologiczne.

Tarnowski, J. (1993). Jak wychowywać? Warszawa: Wydawnictwo Akademii Teologii Katolickiej.

Tarnowski, J. (2003). Jak wychowywać? W ogniu pytań. Ząbki: „Apostolicum“.

Tomas, I. (2016). Sprawozdanie z XXX Letniej Szkoły Młodych Pedagogów. Katowice - Wisła, 12-16 września 2016. Parezja. Czasopismo Forum Młodych Pedagogów przy Komitecie Nauk Pedagogicznych PAN, 2(6), s. 178-185. 